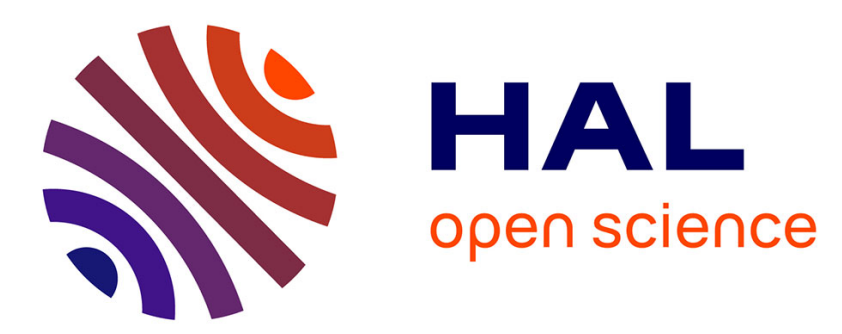

\title{
Assessment of open thermodynamic system concepts for fluviokarst temperature calculations - an example, the Cent-Fonts resurgence (Hérault, France)
}

\author{
Philippe Machetel, D. A. Yuen
}

\section{- To cite this version:}

Philippe Machetel, D. A. Yuen. Assessment of open thermodynamic system concepts for fluviokarst temperature calculations - an example, the Cent-Fonts resurgence (Hérault, France). Hydrology and Earth System Sciences Discussions, 2014, 11, pp.169-198. 10.5194/hessd-11-169-2014 . hal-01358348

\author{
HAL Id: hal-01358348 \\ https://hal.science/hal-01358348
}

Submitted on 31 Aug 2016

HAL is a multi-disciplinary open access archive for the deposit and dissemination of scientific research documents, whether they are published or not. The documents may come from teaching and research institutions in France or abroad, or from public or private research centers.
L'archive ouverte pluridisciplinaire HAL, est destinée au dépôt et à la diffusion de documents scientifiques de niveau recherche, publiés ou non, émanant des établissements d'enseignement et de recherche français ou étrangers, des laboratoires publics ou privés. 


\section{Assessment of open thermodynamic system concepts for fluviokarst temperature calculations - an example, the Cent-Fonts resurgence (Hérault, France)}

P. Machetel ${ }^{1}$ and D. A. Yuen ${ }^{2}$

${ }^{1}$ Geosciences Montpellier, UMR5243 CNRS-Université Montpellier 2, CC60, Place Eugene Bataillon, 34095 Montpellier, Cedex5, France

${ }^{2}$ Minnesota Supercomputing Institute and Department of Geology and Geophysics, University of Minnesota, 310 Pillsbury Dr., SE, Minneapolis, MN 55455, USA

Received: 17 November 2013 - Accepted: 19 December 2013 - Published: 7 January 2014 Correspondence to: P. Machetel (philippe.machetel@laposte.net) Published by Copernicus Publications on behalf of the European Geosciences Union.

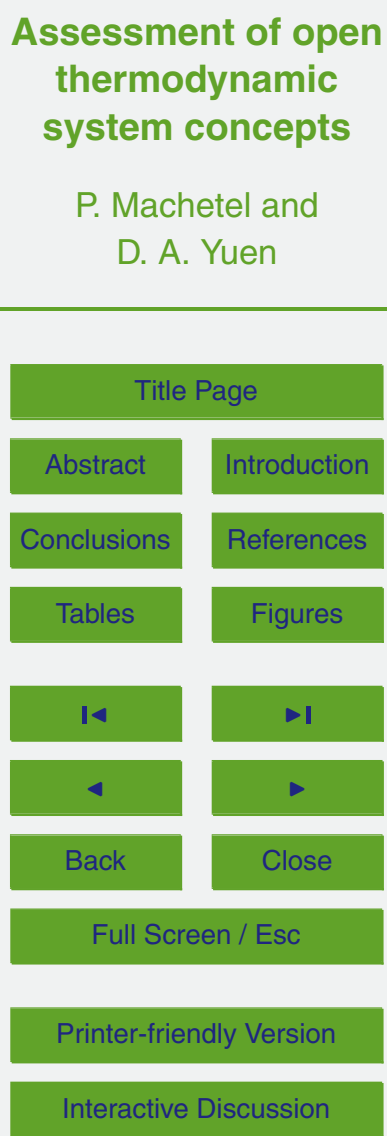




\section{Abstract}

We propose to assess the error done when temperature is considered as a conservative tracer in fluviokarst studies. As a matter of fact, heat exchanges occur between karstic Conduit System (CS) and Porous Fractured Matrix (PFM) that prevents from

5 using this approximation without caution. The conservative tracer approximation boils down to consider the cooling of CS water by PFM flow in an open thermodynamic system where the CS is bounded by an Adiabatic Wall (AW). The resulting CS water temperature contrasts with the one obtained from more complete models $(\mathrm{CW})$, which also take into account heat conduction within the CS, within the PFM, and from the

PFM through CS a Conductive Wall In order to assess first orders of this error, the dimensionless equations, characteristic of CS cooling by PFM, have been solved thanks to Alternate Finite Difference Implicit methods both in AW and CW configurations. Four groups of dimensionless numbers appear in the various terms of energy and mass equations among which the Peclet and Reynolds numbers depict the large morphologic and hydrologic variability of natural karstic systems. A parametric exploration of the differences between $\mathrm{AW}$ and $\mathrm{CW}$ models has then been conducted vs. Peclet numbers (Pe numbers varying from $10^{6}$ to $10^{9}$, at constant CS Reynolds number) and vs. Reynolds numbers ( $R e_{\mathrm{d}}$ varying from $10^{3}$ to $10^{7}$, at constant Peclet number). The error curves bound finite volumes in the Peclet-Reynolds space that converge uniformly to zero for the extreme values of these parameters. However, for Peclet and Reynolds numbers characteristic of realistic fluviokarst configurations, the errors reach finite values, that give first order information assessing the error done by considering temperatures as conservative tracers. Maximum relative errors around $10^{-2}$ (in fact 0.0092 ) have been found varying $P e$; while it remained slightly lower than $0.7 \times 10^{-2}$ imation is presented with the data obtained from the main morphologic and hydrologic properties of the Cent-Font resurgence (Hérault, France). According to the results, the error reached at the output of the fluviokarst is 0.00613 (for $P e=1.4993 \times 10^{8}$ and

Title Page

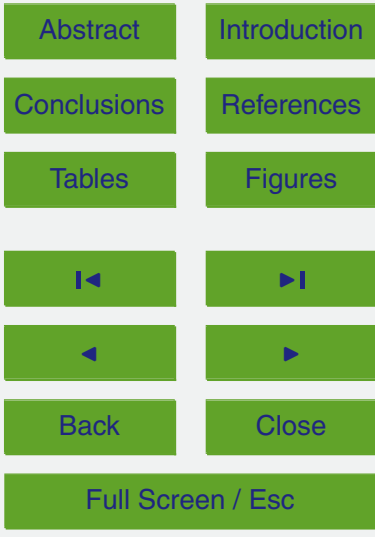

Printer-friendly Version

Interactive Discussion 
$\left.R e_{\mathrm{d}}=4.2969 \times 10^{4}\right)$. When rescaled to the physical domain, this error leads to a temperature difference of $1.77 \mathrm{~K}$ between the $\mathrm{CW}$ and $\mathrm{AW}$ configurations.
HESSD

$11,169-198,2014$

\section{Introduction}

Water needs for irrigation, manufacturing or spring water often lead to consider catch5 ments of karstic aquifers. During recession periods, resurgence of karstic outflows regulates over several months the rainfall fallen during the year on watershed. This property contributes to the equilibrium of downstream ecological systems, which could be jeopardized by unreasonable water exploitation (e.g. Weber and Perry, 2006; Jemcov, 2007). Assessments of karstic hydrologic properties are necessary to prevent such problems. Nowadays, these studies are mainly done by pumping tests experiments. In this paper we propose to study the possibility of reaching such assessments using temperature data that are easier and cheaper to record. However, temperature is not a conservative tracer of energy transfers because underground water exchanges heat by conduction and by advection with the embedding rocks.

15 In spite of this physical limitation, recent studies have been conducted attempting to study the thermal behaviors of surface streams and underground flows from temperature (Kogovsek and Petric, 2010). Constantz $(1998,2008)$ solved iteratively heat transport, adjusting streambed hydraulic conductivity and water temperature, until retrieving the measured temperatures. Tabbagh et al. (1999) also solved heat transport, constrained by vertical temperature measurements, to recover recharge amplitudes. Temperature records covering several years were also used by Benderitter et al. (1993) to calculate the deeps of reservoirs by considering thermal equilibrations between ground water and aquifer rocks.

In spite of short term thermal exchanges, which occur, for example, during flood events in a karstic system, the exchanges between underground water and aquitards need times much longer than the diurnal, meteorological or even seasonal fluctuations. Thus, most of the studies mentioned above rest upon the damping with time

\section{Assessment of open \\ thermodynamic \\ system concepts \\ P. Machetel and \\ D. A. Yuen}

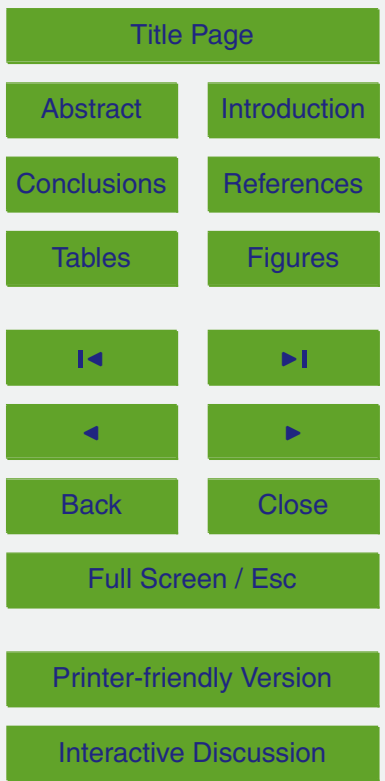


and distances of the short wavelength of temperature (Sinokrot and Stefan, 1993; Luetscher and Jeannin, 2004; Dogwiller and Wicks, 2005). Couplings between flow temperatures, rainfall and discharges have also been used, on an annual basis, by Genthon et al. (2008) to characterize the slow drainage of limestone in lagoon, re5 moving the short wavelength tidal component of temperature poorly correlated with rain temperature. He also used annual temperature variations of spring to determine the deep preferential path of rainfall water in caves (Genthon et al., 2005). Finally, in spite of disturbances due to the meteorological conditions, Karanjac and Altug (1980) also used the temperature records, combined with recession hydrographs, to assess o hydraulic properties, recharge area extent and transmissivity of karstic systems.

The present work aims to use together the properties of open thermodynamic systems to assess the effect of conservative tracer approximation for temperature. However, beyond the problem of heat dissipation, attempts to consider such approximation in karstic media also encounter the natural complexity of hydraulic systems where low 15 resistance Conduit Systems (CS) and rocky Porous Fractured Matrix (PFM) coexist and determine very different flow dynamics. Early models of karst were sometime considering continuous dynamic properties, but new generations of conceptual and numerical models now take into account these differences in transport properties due to the discontinuity of karstic media (e.g. Covington et al., 2009; Luhmann et al., 2011; Covington et al., 2011, 2012). Accordingly, we built our models on a conceptual model of fluviokarst published by White $(2002,2003)$ (Fig. 1a). This model seems particularly well adapted to the study of recession periods, during which physical conditions are the closest as possible of steady situations, since neither flow surface nor internal runoff remain. Furthermore, during these particular periods, evolutions of base flow discharges 25 are slow.

Following the model published by Covington et al. (2011) we propose to consider a cylindrical water saturated CS, separated of PFM by a wall permeable to water. Within this framework, we can calculate the temperature of CS water, assuming, or not, a conservative behavior for temperature. In the first case, mixing occurs in a CS bounded
HESSD

$11,169-198,2014$

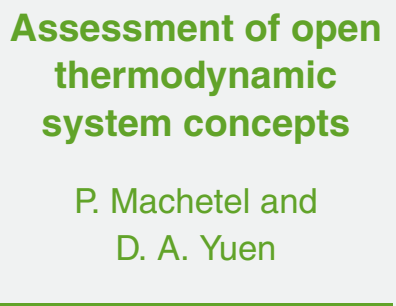

Title Page

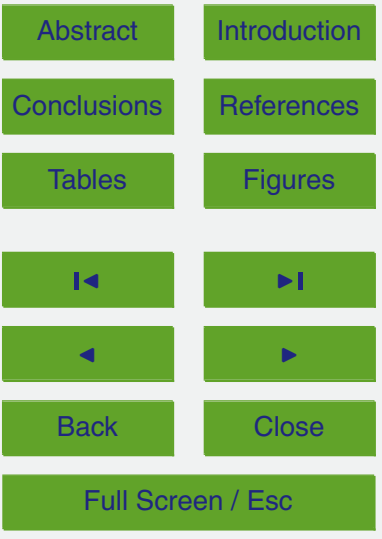

Printer-friendly Version

Interactive Discussion 
by an adiabatic wall, which are only permeable to water coming from PFM, without heat exchange across the wall (Adiabatic Wall cases, AW). In the second cases, the resulting temperature is calculated from more sophisticated models taking also into account conductive heat transfers inside CS, inside PFM and between the PFM and CS 5 (Conductive Wall cases, CW).

For AW cases, we assume that the structure of the CS is cylindrical with an axial coordinate $x$. This cylinder can be split in a sequence of open thermodynamic systems segments, which inputs and outputs are successively connected (Fig. 1b). Each segment of the sequence is a Control Volume (CV), representing a slice of CS and 10 its surrounding PFM. Mass and energy balances will be checked on each of these segments. Conversely, in the CW configuration, we consider radial $r$ and axial $x$ coordinates to describe the heat transfers between CS and PFM. Thus, the evolution of cooling in the CS along the $x$ coordinate depends on the heat dispersion through the CS wall and on the mixing of intrusive water with CS flows (Fig. 1c).

15 As a quite common feature of karstic systems, we will consider that the PFM far field temperature, $T_{\infty}$, is constant through time and equal to the averaged over years, surface, temperature (Lovering and Goode, 1963). Thus, according to the season, matrixconduit flow may either cools or heats the CS water. In the following, we will consider a cooling configuration, consistently with the choice of a dry recession period. With the AW configuration, two flows enter CS. The first is the intrusive swallow zone flow the beginning of the CS. The second is the matrix-conduit flow that enters, at $T_{\infty}$, all along the CS. Conversely, with the CW configuration, the swallow zone intrusive flow at the beginning of the CS still exists but, conduction of heat, through the CS wall along the $\mathrm{CS}$, modifies the narrow temperature in the PFM that changes the temperature of the matrix-conduit flow entering through the CS wall.

The theoretical physical aspects and the dimensionless scaling of AW and CW configurations are developed in Sect. 2. In Sect. 3 we describe the numerical approach used to solve the equations. Section 4 is devoted to an exploratory study of AW vs. CW errors. The results are summarized and discussed in Sect. 5 while geological and
HESSD

$11,169-198,2014$

Assessment of open

thermodynamic

system concepts

P. Machetel and

D. A. Yuen

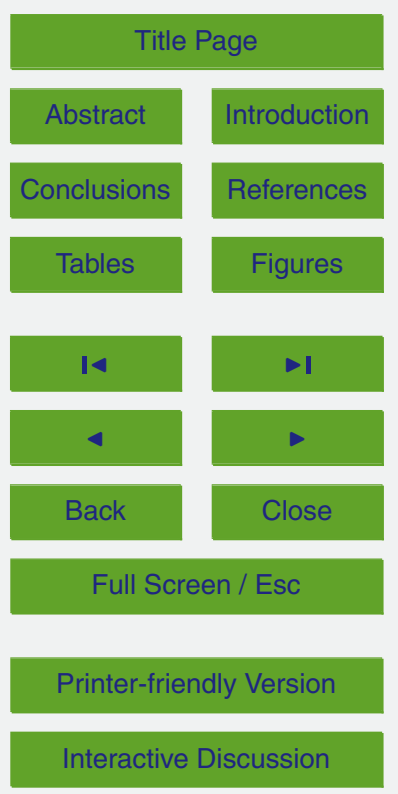


hydrological descriptions of the Cent-Fonts fluviokarstic system are given in the annex part.

\section{Theoretical approach}

Karstic conduit systems are often impossible to penetrate for direct detailed explo5 rations. Considering their local diversity and complexity it is necessary to consider open thermodynamic systems, which offer integrated point of view and simplify the physical system into black-boxes that are controlled by global mass and/or energy considerations between inputs and outputs. Without detailed knowledge of on field properties, local access or measurements, we have to renounce to "detailed" descriptions of phe10 nomena occurring in the heart of karstic system. This also entails, simplifying hypotheses as the one, used in this work, of a cooling conduit system continuously gaining water (AW configuration) and water and heat (CW configuration) through the porous wall of the conduit.

The mass and energy conservation equations have been written for both AW and CW configurations, considering water as a Boussinesq fluid, with constant thermal capacity, thermal expansion and density. Then, water motion forms a zero-divergence velocity field (Eq. 1) in the PFM and in the CS. All the notations used in the paper are gathered in Table 1.

$\operatorname{div}(\boldsymbol{v})=0$

For the AW cases, the Ostrogradsky theorem can be applied to the CV formed by each of the slice of CS and PFM. It allows converting the volume integrals into flux integrals over the surfaces delimitating these CV. Simple mathematical transformations lead to mass continuity equations (Eq. 2) where $Q_{\mathrm{m}, n}$ represents the part of matrixintrusive flow in the $n$th and $Q_{0, n}$ the outgoing flow. In the first slice of the sequence,

Assessment of open

thermodynamic

system concepts

P. Machetel and

D. A. Yuen

Title Page

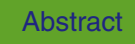

Introduction

Conclusions

Tables

References

Figures

14

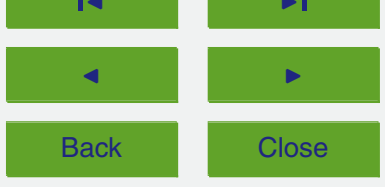

Full Screen / Esc

Printer-friendly Version

Interactive Discussion 
the intrusive flow is the intrusion at the swallow zone while, in the last, the output flow is the resurgence discharge at the base level.

HESSD

$Q_{\mathrm{m}, n}+Q_{\mathrm{i}, n}=Q_{\mathrm{o}, n}$

$11,169-198,2014$

5 If we consider now the conservation of energy in each slice, the first law of thermodynamics stipulates that the internal energy variations are equal, there, to the variation of energy observed between the incoming and outgoing flows. The generality of such physical conditions and their accurate descriptions in terms of thermodynamic functions are given in Vidal (1997) or in Van Wylen and Sonntag (1985) books. Then, the energy budget can be described by a classical mixing equation for temperature (Eq. 3), which can be associated with the mass conservation equation (Eq. 2) to get a system of two equations and two unknowns (temperature or discharge) relevant in the AW context.

$Q_{\mathrm{i}, n} T_{\mathrm{i}, n}+Q_{\mathrm{m}, n} T_{\mathrm{m}, n}=Q_{\mathrm{o}, n} T_{\mathrm{o}, n}$

Equation (2) can be written in terms of velocity along the CS axis and integrated, at distance $x$ from the swallow zone, to calculate the fluid velocity in the $n$th slice of the CS (Eq. 4).

$v_{x}(x+\delta x, 0)=v_{x}(x, 0)-\frac{2 \delta x}{R_{\mathrm{H}}} v_{\mathrm{r}}\left(x, R_{\mathrm{H}}\right)$

A further combination of Eqs. (2) and (3) allows linking the input and output temperatures of the $n$th slice of the CS to calculate the evolution of CS temperature in the AW sequence (Eq. 5). This 1-D equation will be solved thanks to a finite differences scheme.

${ }_{25} \frac{T(x+\delta x, 0)-T(x, 0)}{\delta x}=\frac{2}{R_{\mathrm{H}}} \frac{v_{\mathrm{r}}\left(x, R_{\mathrm{H}}\right)}{v_{x}(x, 0)}\left[T(x+\delta x, 0)-T_{\infty}\right]$

Assessment of open

thermodynamic

system concepts

P. Machetel and

D. A. Yuen

Title Page

Abstract

Introduction

Conclusions

Tables

References

Figures

14

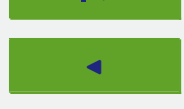

Back

Close

Full Screen / Esc

Printer-friendly Version

Interactive Discussion 
The application of the Ostrogradski theorem to the CW configuration requires distinguishing two areas corresponding to CS and PFM. In the CS, which shape cylindrical has a total length $L$ and hydraulic radius $R_{\mathrm{H}}$, the fluid velocity has no radial component $\left(v_{\mathrm{r}}=0\right)$ but only one axial component, $v_{x}$. In the PFM, water velocity has only one radial 5 component $v_{\mathrm{r}}$. The CS wall, which delimitates the two zones, is located at the radial position $R_{\mathrm{H}}$. It is permeable to the matrix-conduit flow and to heat transfers. Within this context, the continuity equation (Eq. 1) leads to Eqs. (6) and (7) that describe the radial and axial components of the water velocity in the $\mathrm{CV}$.

$v_{\mathrm{r}}(x, r)=-\frac{Q_{\mathrm{m}}}{2 \pi L r} ; v_{x}(x, r)=0 ; x \in[0, L] ; r \geq R_{\mathrm{H}}$

$10 \quad v_{\mathrm{r}}(x, r)=0 ; v_{x}(x, r)=\frac{1}{\pi R_{\mathrm{H}}^{2}}\left[Q_{\mathrm{i}}+Q_{\mathrm{m}} \frac{x}{L}\right] ; x \in[0, L] ; r<R_{\mathrm{H}}$

Two more equations are necessary to take into account the thermal energy transfers between CS and PFM. Extending previous works by Long and Gilcrease (2009), Sinokrot and Stefan (1993) or Covington et al. (2011), we calculate CS temperature 15 through an extended heat conduction-dispersion, steady-state equation, adding one more term to describe the cooling effects of the cold matrix-conduit advective flow through the CS wall (Eq. 8).

$v_{x} \frac{\partial T}{\partial x}=D_{\mathrm{w}}\left[\frac{\partial^{2} T}{\partial x^{2}}+\frac{2}{R_{\mathrm{H}}} \frac{\partial T}{\partial r}\left(x, R_{\mathrm{H}}\right)\right]-\frac{2 v_{\mathrm{r}}\left(x, R_{\mathrm{H}}\right)}{R_{\mathrm{H}}}\left[T\left(x, R_{\mathrm{H}}\right)-T(x, 0)\right] ; x \in[0, L] ; r<R_{\mathrm{H}}$

20 In order to lighten the notations, the dependencies of $T$ and $v_{x}$ on the $x$ and $r$ coordinates have not been written in Eq. (8) except when the values of these fields are taken at particular locations (as $R_{\mathrm{H}}$ ). Beside, in PFM, we apply a steady-state cylindrical temperature equation (Eq. 9) with no horizontal advection.

$v_{\mathrm{r}} \frac{\partial T}{\partial r}=D_{\mathrm{m}} \Delta T ; x \in[0, L] ; r \geq R_{\mathrm{H}}$
HESSD

$11,169-198,2014$

Assessment of open

thermodynamic

system concepts

P. Machetel and

D. A. Yuen

Title Page

Abstract

Introduction

Conclusions

Tables

References

Figures

14

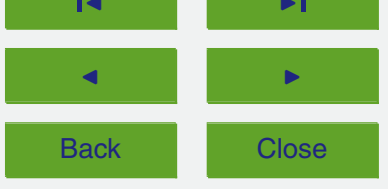

Full Screen / Esc

Printer-friendly Version

Interactive Discussion 
In Nature, the large variability of karstic system geometry and hydrology entails rescaling the equations in dimensionless variables and numbers. Karsts generally display CS lengths much longer than hydraulic radii, with underground path lengths ranging from a few tens of meters to kilometers while cave widths vary from a few tens 5 of centimeters to tens of meters. Therefore the aspect ratio $R_{\mathrm{H}} / L$ of the problem will probably constitute an influential parameter implying several orders of magnitude to describe significant ranges of potential karstic structures. Second and third aspects, which will obviously have first order effects on the cooling of CS temperature, are the temperature difference between intrusive water at the swallow zone $\left(T_{\mathrm{i}}\right)$ and far field 10 temperature $\left(T_{\infty}\right)$; but also the relative importance of intrusive flow at swallow zone $\left(Q_{\mathrm{i}}\right)$ and matrix-conduit flow $\left(Q_{m}\right)$. Finally, we also need to recall the relative values of $C S$ and PFM thermal diffusivities (Dw and Dm) as an important term for the level of heat dispersion through the CS wall in the CW cases.

Therefore, we have rewritten the equations using the length $L$ as distance scale and 15 the discharge difference between the resurgence and the swallow zone (divided by the CS surface) for the velocity scale $V=\left(Q_{\mathrm{S}}-Q_{\mathrm{i}}\right) /\left(\pi R_{\mathrm{H}}^{2}\right)$. A natural time scale $\tau$ is obtained from the previous ones with $\tau=L / V$. For the scaling of temperature, we have used the far field temperature as reference; and the temperature difference between the intrusive flows, $T_{\mathrm{i}}$, and the far field, $T_{\infty}$, as temperature scale (see Table 1). With these conventions, the equations of temperature for the AW cases (Eq. 5) and the CW cases (Eqs. 8 and 9) take respectively the dimensionless forms depicted in Eqs. (10)(12) where all the variables are now dimensionless.

$$
\begin{aligned}
& \frac{T(x+\delta x)-T(x)}{\delta x}=\frac{4 P e}{R e_{D} \operatorname{Pr}} \frac{v_{\mathrm{r}}\left(x, R_{\mathrm{H}}\right)}{v_{x}(x, 0)} T(x, 0) \\
& v_{x}(x, 0) \frac{\partial T}{\partial x}=\frac{1}{P e} \frac{\partial^{2} T}{\partial x^{2}}+\frac{4}{R e_{D} P r} \frac{\partial T}{\partial r}\left(R_{\mathrm{H}}\right)+\frac{4 P e}{R e_{D} P r} v_{\mathrm{r}}\left(x, R_{\mathrm{H}}\right)\left[T(x, 0)-T\left(x, R_{\mathrm{H}}\right)\right] ; \\
25 \quad & x \in[0,1] ; r<\frac{R_{\mathrm{H}}}{L}
\end{aligned}
$$

HESSD

$11,169-198,2014$
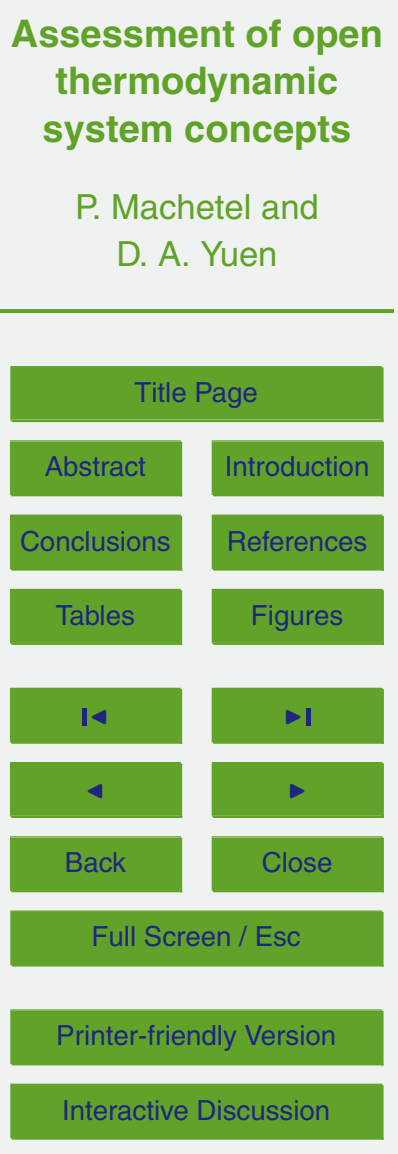

Interactive Discussion 
$v_{\mathrm{r}} \frac{\partial T}{\partial r}=\frac{D_{M}}{D_{W}} \frac{1}{P e}\left[\frac{\partial^{2} T}{\partial x^{2}}+\frac{\partial^{2} T}{\partial r^{2}}+\frac{1}{r} \frac{\partial T}{\partial r}\right] ; x \in[0,1] ; r \geq \frac{R_{\mathrm{H}}}{L}$

In these Eqs. (10)-(12), four groups of dimensionless numbers, combining Peclet, Prandtl and Reynolds numbers, appear in the various terms as: $1 / P e$ (Eq. 11); $51 /\left(R e_{\mathrm{d}} P r\right)$ (Eq. 11), $\mathrm{Pe} /\left(R e_{\mathrm{d}} P r\right)$ (Eqs. 10 and 11) and $D_{\mathrm{m}} /\left(D_{\mathrm{w}} P e\right)$ (Eq. 12).

The Prandtl Number, Pr, which mathematical expressions is recalled in Table 1, measures the ratio of momentum diffusivity (kinematic viscosity) and thermal diffusivity. It's value depends only on the physical properties of the fluid that explain that, in the following, we will consider it is reasonably well known and we will not use it as a target in the 10 parametric study. Conversely, the Reynolds number, $R e$, which measures the relative importance of inertial to viscous terms; and the Peclet number, $P e$, which measures the ratio of heat flow advection to heat diffusion depend both on physical properties of the fluid (like thermal diffusivity or kinematic viscosity), and on the length and hydraulic radius, $L$ and $R_{\mathrm{H}}$ of the system since, in the case of a cylindrical structure, $R e_{\mathrm{d}}$ is not calculated with the CS length, $L$, but with the hydraulic diameter, $2 R_{\mathrm{H}}$.

The first of these dimensionless groups, $1 / P e$, appears in the $\mathrm{CW}$ configuration equations where it characterizes the conductive dissipation term in the CS. The second group, $1 /\left(R e_{\mathrm{d}} P r\right)$, also appears in the $\mathrm{CW}$ framework where it measures the conductive dispersion of heat from CS to PFM through the CS wall. The third, $P e /\left(R e_{d} P r\right)$ appears in both CW and AW contexts. It corresponds to the advection of cold water from PFM to the CS. The fourth group, $D m /(D w P e)$, appears only in Eq. (11) where it modulates the conductive dispersion from the CS in the PFM. However, the ratio of PFM to CS thermal diffusivities, $D m / D w$, and the Prandtl number involve only water and rocks physical constants. They are less subject to broad uncertainties than the numbers that involved the large variability of the karst hydrologic properties (lengths, hydraulic diameters, temperatures, discharges, etc. ...). This is why, we have chosen, in the following, to restrain the parametric exploration to the Reynolds and Peclet numbers. Thus, the dimensionless groups $\left(R e_{\mathrm{d}} P r\right)$ that appears in front of the advection

Assessment of open

thermodynamic

system concepts

P. Machetel and

D. A. Yuen

Title Page

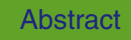

Introduction

Conclusions

Tables
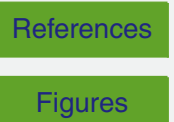

14

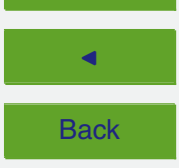

-1

Close

Full Screen / Esc

Printer-friendly Version

Interactive Discussion

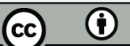


term of Eq. (9) and in front of the advection and dispersion terms of Eqs. (10) and (11) include information about the geometrical aspect ratio $2 R_{\mathrm{H}} / L$ of the fluviokarst. Considering the huge variety of these geometrical properties in karstic system we have chosen to conduct a broad parametric exploration of these dimensionless parameters.

5 Furthermore, as Peclet numbers are equivalent to the products of Prandtl numbers by Reynolds numbers, the parametric exploration based on broad ranges of Peclet and Reynolds numbers also implicitly encompasses this parameter.

\section{Numerical modeling}

Two numerical programs have been written to solve the mass and energy conservation 10 equations in $\mathrm{AW}$ (Eq. 10) and CW configurations (Eqs. 11 and 12). Both numerical codes are based on iterative second-order accurate, finite-difference methods (e.g. Douglas and Rachford, 1956). For AW cases, the numerical code computes temperature in the CS along the axial direction while, for CW configuration, ADI scheme computes temperature alternatively in radial and axial directions successively in CS and in 15 PFM, the coupling between the two media being ensured by sharing common boundary conditions along the CS wall. Laplace operators are solved over $100 \times 500$ nodes grid points respectively in the radial and axial directions. Computational process stops when the evolution of solutions between two time-steps falls below $10^{-8}$ for each point of the grid.

20 For AW configuration the finite-difference scheme is 1-D along the CS axis. As a boundary condition at $x=0$ (entry of the CS at the swallow zone), the CS temperature is maintained to those, $T_{\mathrm{i}}$, of the intrusion; while the CS temperature at $x=L$ (resurgence output) evolves freely. For CW cases, the CS boundary conditions of temperature at $x=0$ and at $x=L$ are the same. However, temperature is now solved in

PFM, for which the thermal external boundary is equal to the far field temperature $\left(T_{\infty}\right)$. The temperature computed at the CS wall $\left(r=R_{\mathrm{H}}\right)$, during the CS temperature resolution, serve as lower radial boundary condition for the PFM temperature resolution.

Assessment of open

thermodynamic

system concepts

P. Machetel and

D. A. Yuen

Title Page

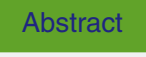

Introduction

Conclusions
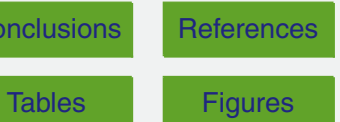

Tables

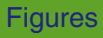

14

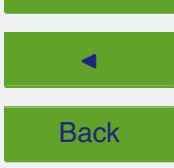

I

Close 
Therefore, the iterative process couples the boundary temperature of the two CS and PFM media thanks to the effect of the heat dispersion from CS to PFM and the cooling of CS water by the PFM flow.

A first illustrative case has been computed using the hydrologic and morphologic 5 properties of the Cent-Font fluviokarstic system (Hérault France), which main geological and hydrological properties are described in annex. The values of the intrusion and resurgence discharges $\left(Q_{\mathrm{i}}=0.055\right.$ and $\left.Q_{\mathrm{s}}=0.337 \mathrm{~m}^{3} \mathrm{~s}^{-1}\right)$, of the intrusion and far field temperatures $\left(T_{\mathrm{i}}=295.25 \mathrm{~K}\left(22.1^{\circ} \mathrm{C}\right), T_{\infty}=285.35 \mathrm{~K}\left(12.2^{\circ} \mathrm{C}\right)\right)$ have been recorded or assessed from the summer 2005, pumping test campaign (Ladouche 10 et al., 2005). Reasonable morphologic properties $\left(L=5000 \mathrm{~m}, R_{\mathrm{H}}=5 \mathrm{~m}\right)$ and realistic water thermal diffusivity $\left(D_{\mathrm{w}}=1.4310^{-7} \mathrm{~m}^{2} \mathrm{~s}^{-1}\right)$ and porous matrix thermal diffusivity $D_{\mathrm{m}}=4.0310^{-6} \mathrm{~m}^{2} \mathrm{~s}^{-1}$ (Pechnig et al., 2007) have been use. These values lead to dimensionless parameters $P e=1.499310^{8}, R e_{d}=4.296910^{4}, P r=6.9783$ and $D_{\mathrm{M}} / D_{\mathrm{W}}=9.9088$, which have been introduced in the numerical codes to calculate the 15 illustrative example.

The temperature field obtained for PFM and CS in the CW configuration (Fig. 2) has been rescaled in physical space before drawing. It shows the cooling of the intrusive CS flow by the cold PFM flow. The CS temperature follows a monotonic decrease from the swallow zone to the resurgence output along the $x$ axial direction. For low values of $x$, the conductive heat transfers from CS to PFM induce step thermal boundary layers on the PFM side of the CS wall. However, in the PFM, away from the CS wall, these thermal boundary layers damp with the radial distance and the temperature converge rapidly toward the far field temperature.

Now, from Eq. (10), it is possible to calculate the CS cooling in the AW configuration 25 as a function of the distance $x$ from the intrusion zone. This result is compared in Fig. 3 with the temperature obtained from the CW model (Fig. 2). With the AW configuration, the CS temperature is lower than the one of the CW model. This result ensues from artificially overestimated cooling conditions in the AW configuration, with PFM flow incoming in the CS at far field temperature. This is not the case in the CW model, for
HESSD

$11,169-198,2014$

Assessment of open

thermodynamic

system concepts

P. Machetel and

D. A. Yuen

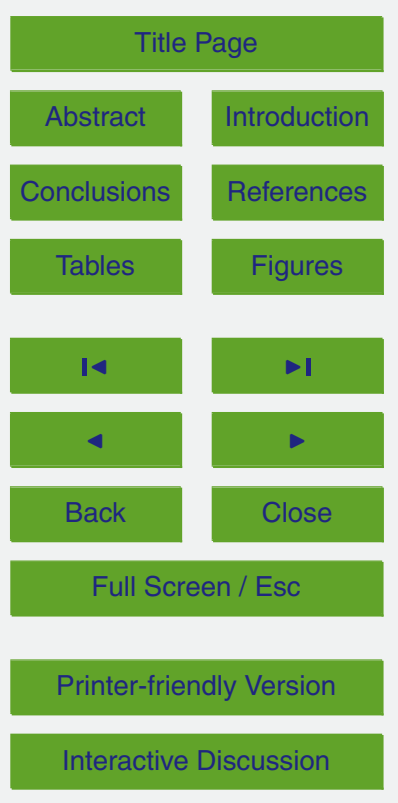


which conductive and dispersive effects heat the PFM flow before it enters CS. As a matter of fact, the two curves diverge rapidly for the low values of $x$, near the beginning of the CS where the thermal gradients in PFM are the steepest. For large $x$, far from the intrusion, the two curves converge and should gather at infinite $x$ limit.

The difference of temperature obtained between the CW and AW configurations contain first-order information about the accuracy of the conservative temperature approximation (AW case) even if it is not sufficient to completely unroll the other sources of errors. They are unavoidable to models, which assume laminar, water saturated, cylinder, cooling CS. It is clear that this work is a first approach that needs to be completed by further studies assessing the other approximations. However, keeping this in mind, we will consider in the following that the temperature differences between $\mathrm{CW}$ and $\mathrm{AW}$ cases, along the axial direction in the CS, are representative of the error done considering AW in fluviokarst conduit.

\section{Parametric exploration}

15 In the following we will consider the ratio of the temperature difference between the $\mathrm{CW}$ and $\mathrm{AW}$ cases divided by the $\mathrm{CW}$ temperature as a measure of the error $\varepsilon(x)$. Equation (13) gives it dimensionless expression, $T_{\mathrm{AW}}$ and $T_{\mathrm{CW}}$ being the dimensionless results of numerical inversions of Eqs. (10)-(12).

Figure 4 shows the error $\varepsilon \xi$ vs. Pe numbers, at constant $R e_{\mathrm{d}}$ (two top panels); and vs. $R e_{\mathrm{d}}$, at constant $P e$ (two bottom panels). Curves of left panels display the errors $\epsilon(x)$ along the axial direction of the CS, while right panels give synthetic views of the final errors at the system output.

25 The top, left panel, $\epsilon(x)$ curves of Fig. 4 have been obtained for $P e$ ranging from $10^{5}$ to $10^{11}$ at $R e_{\mathrm{d}}=4.2969 \times 10^{4}$ (the value obtained for the Cent-Fonts case). At

Assessment of open

thermodynamic

system concepts

P. Machetel and

D. A. Yuen

Title Page

Abstract

Introduction

Conclusions

Tables

References

Figures

14

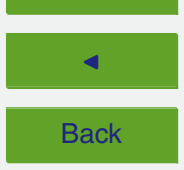

$>1$

$>$

Close 
first glance, it appears that, in all the cases, $\varepsilon(x)$ starts from zero and remains, with increasing $x$, below a maximum value around 0.01 . For the low values of $P e\left(10^{6}\right.$ and $5 \times 10^{6}$; brown and red curves), $\varepsilon(x)$ increases regularly with $x$. However, decreasing $P e$ decreasing from $5 \times 10^{6}$ to $10^{6}$ seems induce uniform convergences of $\epsilon(x)$ to 0 . 5 Conversely, the $\varepsilon(x)$ curves also converge to 0 for high values of $P e\left(P e=10^{9}\right.$ and $5 \times 10^{8}$; purple and dark blue curves) but displaying local maxima near the intrusion zone. There, they reach maximum values followed by monotonic decreases to 0 for increasing values of $x$. For intermediate values of $P e$, between these extremes cases, the $\varepsilon(x)$ curves reach finite values approximately bounded by 0.01 (in fact 0.0092 , for $10 P e=7 \times 10^{7}$ ).

If we consider Eqs. (11) and (12) for infinite limit of $\mathrm{Pe}$, the conductive terms (that are multiplied by $1 / P e$ ) and the dispersion term (multiplied by $1 /\left(R e_{\mathrm{d}} P r\right)=\left(2 R_{\mathrm{H}} L\right) / P e$ ) tend toward zero and therefore cancel. Then, the CS cooling depends only on the advection of cold water from PFM that is precisely the AW approximation. In such con-

ditions, it is clear that $\varepsilon(x)$ converges to 0 . This result is consistent with the physical meaning of $P e$ numbers, which measure the relative importance of advection to diffusion in systems. If diffusion becomes negligible, dispersion also becomes negligible in front of the cooling by the PFM flow. However, in this case, the shapes of the $\varepsilon(x)$ curves for low values of $x$ near the intrusion area, characterize the locations where the conductive heat flows from CS toward PFM remain relatively the most important.

Now, the uniform convergence to 0 , observed at low values of $P e$ numbers for the $\varepsilon(x)$ curves of the top, left panel of Fig. 4, comes from the physical situation implicitly encountered when $P e$ decreases at constant $R e_{\mathrm{d}}$. Indeed, considering that the uncertainties on the physical parameters of water are sufficiently low to assume that most of the uncertainties on the dimensionless parameters come from the hydrologic properties; a constant $R e_{\mathrm{d}}$ means a constant $\left(R_{\mathrm{H}} V\right)$ product (see Table 1). If we consider a constant velocity scale $V$, this also implies a constant $R_{H}$. If we consider simultaneously a decrease of $P e$, this can only be obtained by a decrease of the length scale $L$. Then, with constant $R_{\mathrm{H}}$ and $V$, but decreasing $L$, the total surface of the CS wall,
HESSD

$11,169-198,2014$

Assessment of open

thermodynamic

system concepts

P. Machetel and

D. A. Yuen

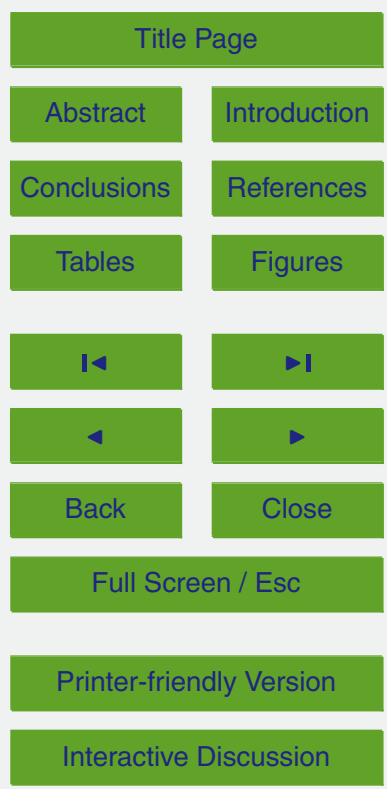


which is equal to $2 R_{\mathrm{H}} L$, decreases that induces an implicit increase of the flux by unit of surface. Such situation enhances the relative importance of PFM advection in front of heat diffusion and dispersion; the physical conditions become closer to those resulting from the AW approximation; and explain the uniform convergence of the error toward 50 (Fig. 4, top panels). However, conversely to the situation generated with the high $\mathrm{Pe}$ values, the resulting errors are no more localized near the origin but are now regularly distributed along the CS axial direction, inducing a cumulative behavior proportional to $x$.

The right, top panel of Fig. 4 gives a synthetic view of the error, vs. Pe numbers at 10 the output of the system. It indicates the existence of an intermediate zone of $P e$ for which the error $\xi(L)$ is finite but remains lower than 0.01 (a maximum value of 0.0092 being reached for $P e=7 \times 10^{7}$ ). It is interesting to note that the Cent-Fonts resurgence illustrative example, given in Figs. 2 and 3, naturally falls within this range of finite but bounded error.

15 Let's now consider the physical situation involved by varying $R e_{\mathrm{d}}$, at constant $P e$. From Table 1, it appears that decreases of $R e_{\mathrm{d}}$ are equivalent to decreases of the hydraulic radius (at constant velocity scale). This decrease of $R_{\mathrm{H}}$ enhances the relative importance of the advection through the wall in Eq. (12) (multiplied by the group $P e /\left(R e_{\mathrm{d}} P r\right)=L /\left(2 R_{\mathrm{H}}\right)$. These considerations explain why we retrieve, for low $R e_{\mathrm{d}}$ numbers, the shapes of $\epsilon(x)$ curves, found in the previous paragraph for the high $P e$, thus displaying more abrupt variations at low values of $x$. A significant enhancement of the error $\varepsilon(x)$ occurs near the intrusion zone where conductive dispersion is the most important. However, this behavior decreases quickly toward zero when the advection cooling from PFM becomes preeminent with distance $x\left(R e_{\mathrm{d}}=10^{3}\right.$ and $10^{4}$; purple and dark blue curves).

Conversely, it results, from increases of $R e_{\mathrm{d}}$, at constant $P e$, that $R_{\mathrm{H}}$ increases. This induces that Eqs. (10) and (12) describe now closer physical situations; and that $\varepsilon(x)$ converges to 0 (Fig. 4, bottom panels). The shapes of the $\varepsilon(x)$ curves are characteristic of errors regularly distributed along the CS axis $\left(R e_{\mathrm{d}}=10^{7}\right.$, red curve of Fig. 4 left,

HESSD

11, 169-198, 2014
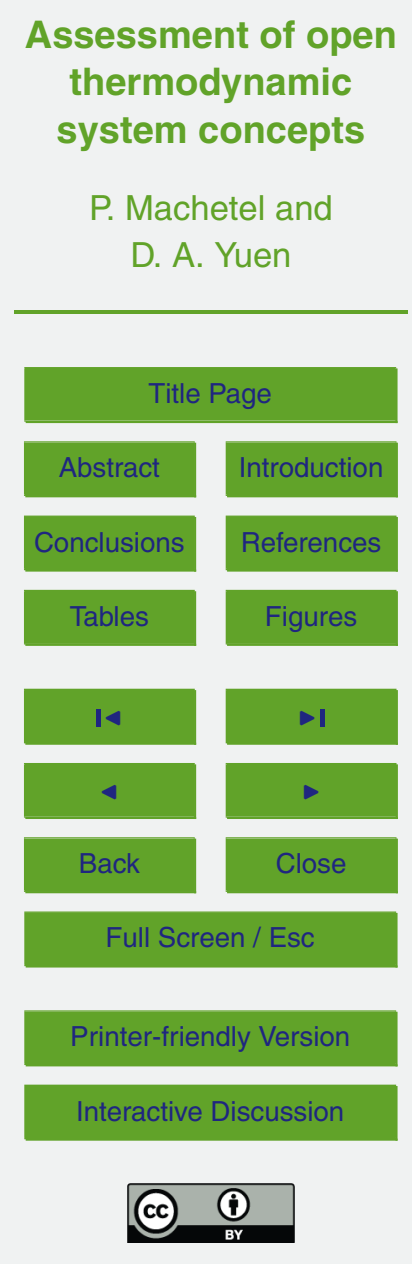
bottom panel). Right, bottom panel of Fig. 4 gives now a synthetic view of the output error vs. $R e_{\mathrm{d}}$ number. Again, it indicates the existence of a zone of intermediate values of $R e_{\mathrm{d}}$, for which the errors become maxima, but remains lower than 0.007 (a maximum value 0.0062 being reached for $R e_{\mathrm{d}}=10^{5}$ ).

\section{Summary and discussion}

In this work we assumed conservative tracer behavior for temperature that was corresponding to Adiabatic Wall (AW) cases for the conduit system. Conversely, we also tested a more completed model of the mixing process, occurring between CS and PFM flows, by taking into account heat dispersion through the CS wall $(\mathrm{CW})$, heat dissipation within the conduit, heat dissipation in the porous fractured matrix and convective cooling of the CS by PFM flow (Eqs. 11 and 12). The dimensionless forms of mass and energy conservation equations have been rewritten for both AW and CW configurations, leading to a new system of equations, which entail four groups of dimensionless numbers to drive their various terms. Numerical, finite-difference programs have been to solve these equations. This allows comparing the CS cooling temperatures obtained along the axial direction of the CS, with the AW and CW approximations; and giving a first order of the error, $\varepsilon(x)$, done applying the AW approximation alone.

A large, quantitative, exploration of this error $\varepsilon(x)$ has been done vs. large ranges of $20 P e$ and Reynolds number values ( $P$ e numbers varying from $10^{6}$ to $10^{9}$, corresponding to three orders of magnitude in CS length configurations; and $R e_{\mathrm{d}}$ varying from $10^{3}$ to $10^{7}$, corresponding to four orders of magnitude in the CS hydraulic radius variations). A maximum relative errors around $10^{-2}$ (in fact 0.0092 ) has been found varying $P e$; while it remained slightly lower than $0.710^{2}$ varying $R e_{\mathrm{d}}$. The combination of the $P e$ of these parameters. However it also builds a finite bounded volume for the median

HESSD

$11,169-198,2014$

Assessment of open

thermodynamic

system concepts

P. Machetel and

D. A. Yuen

Title Page

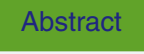

Introduction

Conclusions

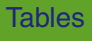

Figures

14

4

Back

Close

Full Screen / Esc

Printer-friendly Version

Interactive Discussion 
values of these dimensionless parameters as it is illustrated by the results obtained with the Cent-Fonts fluviokarstic system.

From these results, it seems now possible to assess a first order value of the error done considering temperature as a conservative tracer at the Cent-Font resurgence.

5 According to the curves displayed in Fig. 4, the error $\varepsilon(x)$ reached at the output of the fluviokarst is $\varepsilon=0.00613$ (for $P e=1.499310^{8}, R e_{\mathrm{d}}=4.296910^{4}$ ). When rescaled to the physical domain, this error leads to a temperature difference of $T_{\mathrm{CW}}-T_{\mathrm{AW}}=1.77 \mathrm{~K}$ $(0.00613 \times 288.50)$ between the $\mathrm{CW}$ and $\mathrm{AW}$ configurations. It is interesting to note that it is also possible to get a slightly less accurate assessment of this error directly from 10 from the maximum error values obtained from the curves of Fig. 4: $0.0092 \times 288.5=$ $2.65 \mathrm{~K}$ (from the $\varepsilon(x)$ dependence on $P e$ ); and $0.00620 \times 288.5=1.79 \mathrm{~K}$ (from the dependence on $R e_{\mathrm{d}}$ ).

However, we keep in mind that this work is only a first approach of the assessment of the error done considering temperature as a conservative tracer in fluviokarst. Indeed, among other assumptions we assume steady situations that are never perfectly reached in karstic systems (even if they are approached at least during the driest part of the recession periods). This exploratory study of the influence of the AW vs. CW error has also been established considering that it mostly comes from the uncertainties on the geometric and hydrologic properties of karst, which may reach several orders of magnitude variability. It seems also necessary to recall that the $\mathrm{CW}$ temperature, which is here considered as a reference to calculate the errors, is also an approximation based on steady states, cylindrical geometrical shape and saturated state of the CS. In spite of this, it remains that observation of the cooling effects of far field temperature in the Cent-Fonts resurgence seems consistent with the level of error that is obtained with the comparison of $\mathrm{AW}$ and $\mathrm{CW}$ model. The application of this method to other thermal extrapolation in karstic systems will also raise the question of the propagations of such errors through combinations of hydrologic parameters. Among others, this last point seems promising and will be explored in further works to try to better take
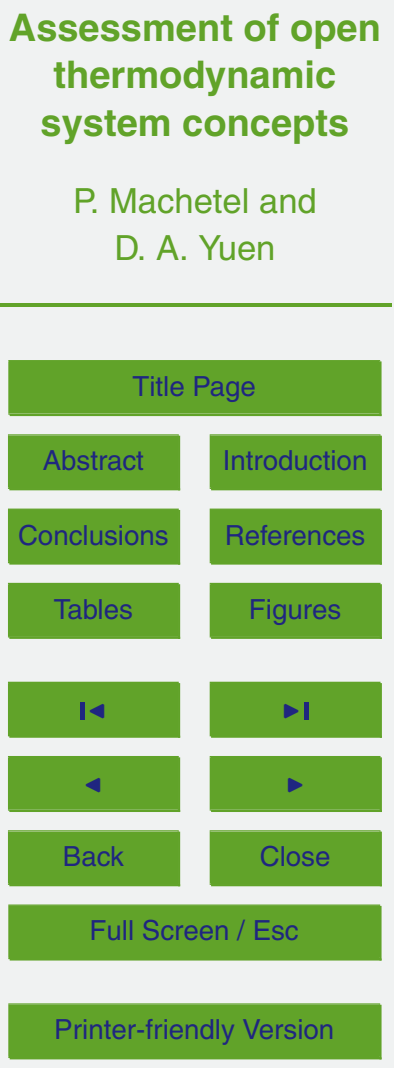

Interactive Discussion 
into account the natural variability of karstic systems and increase the applicability of this method.

\section{Appendix A}

\section{The Cent-Fonts resurgence (Hérault, France)}

5 The Cent-Fonts resurgence is the only outlet of a $40-60 \mathrm{~km}^{2}$ watershed (Fig. 5), located in the north of Montpellier, in the median part of the right bank Hérault River, within a sequence of thick limestone and dolomitic outcrops of Middle and Late Jurassic. Several structural, geological, geochemical and hydrological studies have been devoted to this area for several decades (Paloc, 1967; Camus, 1997; Petelet et al., 10 1998; Schoen et al., 1999; Petelet-Giraud et al., 2000, 2003; Ladouche et al., 2002, 2005; Aquilina et al., 2005, 2006; Marechal et al., 2008; Dörfliger et al., 2009). The watershed is bound at north and northeast by the Cévennes Fault and the Buèges Stream and at south east by the Hérault River corresponding to the base level (approximately $76 \mathrm{~m})$.

15 This area consists of a karst plateau, elevated to 200 to $500 \mathrm{~m}$ during the Late Quaternary and strongly incised during Oligocene by Buèges Stream and Hérault River. The watershed includes the upstream course of the Buèges Stream that flows on the ground surface from the spring to a swallow zone located a few kilometers downstream of Saint-Jean de Buèges (Fig. 5). There, the Buèges Stream leaves a low permeability Triassic terrain to encounters a swallow zone located in bathonian dolomitic layers. After this point, the surface course of Buèges Stream forms a valley dried up most of the year except during high water flows. Then, a surface stream joins the Hérault River a few kilometers upstream from the confluence with the Lamalou stream. The relationship between the Buèges stream swallow zone and the Cent Fonts resurgence was established by tracer experiments (Dubois, 1964; Schoen et al., 1999).

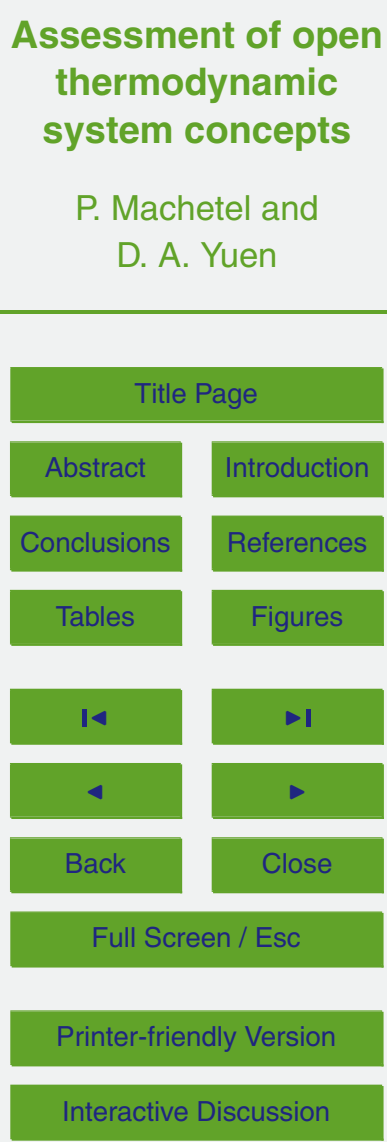


The saturated zone of the Cent-Fonts resurgence system takes place within a 150 to $300 \mathrm{~m}$ thick Bathonian dolomitic layer and, possibly, within an underlying AalenianBajocian layer (Fig. 6). The basic matrix-conduit flow recharge of the aquifer percolates through Oxfordian and Kimmeridgian late jurassic epikarstic layers or directly, 5 by continuous water seepage, from the Buèges riverbed into the Bathonian calcareous dolomite layer (Pételet-Giraud et al., 2000). The Cent-Fonts karst is therefore a mixed-flow karstic system that matches well the White's conceptual model (Fig. 1a) with an intrusive upper stream, located at a swallow zone around $5 \mathrm{~km}$ north of a spring flowing at the base level of the karstic system. Summer discharge of the Cent Fonts 10 resurgence ranges from 0.25 to $0.34 \mathrm{~m}^{3} \mathrm{~s}^{-1}$ (Marechal et al., 2008). The detailed structure of the conduit system (Fig. 6) has been explored by divers, near the resurgence, where it is accessible by speleology (Vasseur, 1993). In the mapped area, the cross section of the CS ranges from 4 to $16 \mathrm{~m}^{2}$ with its largest part located at the end of the conduit (Dörfliger et al., 2009). Most of the time, the resurgence outlets flow into 15 Hérault River through a shallow network of springs that gush out a few tens of centimeters above the karstic base level but also directly through the bottom of the Hérault riverbed (Schoen et al., 1999).

As a studied site for spring water exploitation, the Cent-Fonts resurgence has received much attention since 1997. Numerous field observations, as the gauging of the stream at the swallow zone have been collected for several years. A large pumping test experiment has been conducted during summer 2005 that allows collecting numerous temperatures and hydraulic heads and gauging in several locations, holes and streams (Ladouche et al., 2005).

25 Acknowledgements. The authors thank the "Conseil Général de l'Hérault" for providing the data of the 2005 Cent-Fonts resurgence, pumping test data, obtained under contract by BRGM. We also thank Alexander Calvin, Martin Saar and Andrew Luhmann for friendly and helpful discussions about heat transfers in karstic system. This work has benefited of a special grant of the organization of the International Workshop of Deep Geothermal Systems, Wuhan, China, $30 \quad$ 29-30 June 2012. the Herault River and of the Buèges

HESSD

$11,169-198,2014$
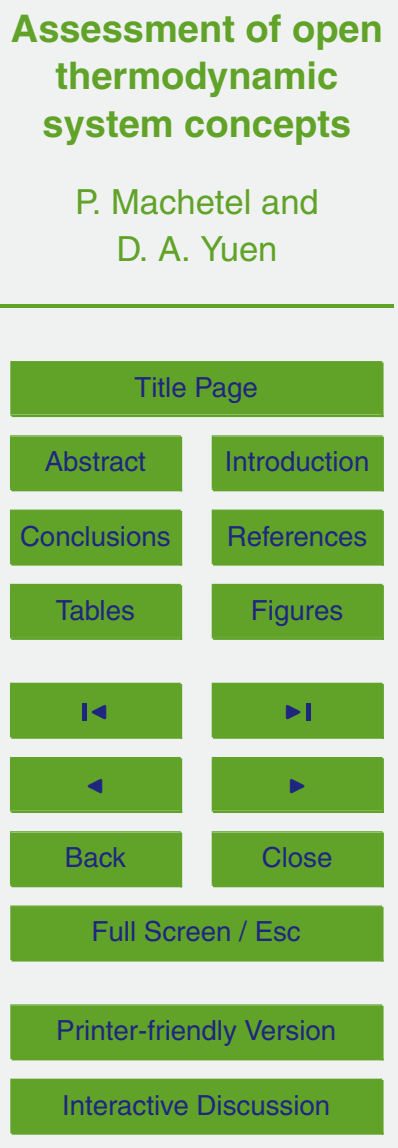


\section{References}

Aquilina, L., Ladouche, B., and Dörfliger, N.: Recharge processes in karstic systems investigated through the correlation of chemical and isotopic composition of rain and spring-waters, Appl. Geochem., 20, 2189-2206, 2005.

5 Aquilina, L., Ladouche, B., and Dörfliger, N.: Water storage and transfer in the epikarst of karstic systems during high flow periods, J. Hydrol., 327, 472-485, 2006.

Aravinth, S.: Prediction of heat and mass transfer for fully developed turbulent fluid flow through tubes, Int. J. Heat Mass Tran., 43, 1399-1408, 2000.

Benderitter, Y., Roy, B., and Tabbagh, A.: Flow characterization through heat transfer evidence in a carbonate fractured medium: first approach, Water Resour. Res., 29, 3741-3747, 1993.

Camus, H.: Formation des réseaux karstiques et creusements des vallées: l'exemple du Larzac meridionnal, Hérault, France, Karstologia, 29, 23-42, 1997.

Constantz, J.: Interaction between stream temperature, stream flow, and groundwater exchanges in Alpine streams, Water Resour. Res., 34, 1609-1615, 1998.

15 Constantz, J.: Heat as a tracer to determine streambed water exchanges, Water Resour. Res., 44, W00D10, doi:10.1029/2008WR006996, 2008.

Covington, M. D., Wicks, C. M., and Saar, M. O.: A dimensionless number describing the effects of recharge and geometry on discharge from simple karstic aquifers, Water Resour. Res., 45, W11410, doi:10.1029/2009WR008004, 2009.

20 Covington, M. D., Luhmann, A. J., Gabrovsek, F., Saar, M. O., and Wicks, C. M.: Mechanisms of heat exchange between water and rock in karst conduit, Water Resour. Res., 47, W10514, doi:10.1029/2011WR010683, 2011.

Covington, M. D., Luhmann, A. J., Wicks, C. M., and Saar, M. O.: Process length scales and longitudinal damping in kart conduits, Mechanisms of heat exchange between water and rock in karst conduit, J. Geophys. Res., 117, P01025, doi:10.1029/2011JF002212, 2012.

Dogwiller, T. and Wicks, C.: Thermal variations in the hyporheic zone of a karst stream, Speleogen. Evol. Karst Aquif., 3, 1-11, 2005.

Dörfliger, N., Fleury, P., and Ladouche, B.: Inverse modeling approach to allogenic karst system characterization, Ground Water, 47, 414-426, doi:10.1111/j.1745-6584.2008.00517.x, 2009.

Douglas, J. and Rachford, H. H.: On the numerical solution of heat conduction problems in two and three space variables, T. Am. Math. Soc., 82, 966-968, 1956.
HESSD

$11,169-198,2014$

\section{Assessment of open \\ thermodynamic \\ system concepts \\ P. Machetel and \\ D. A. Yuen}

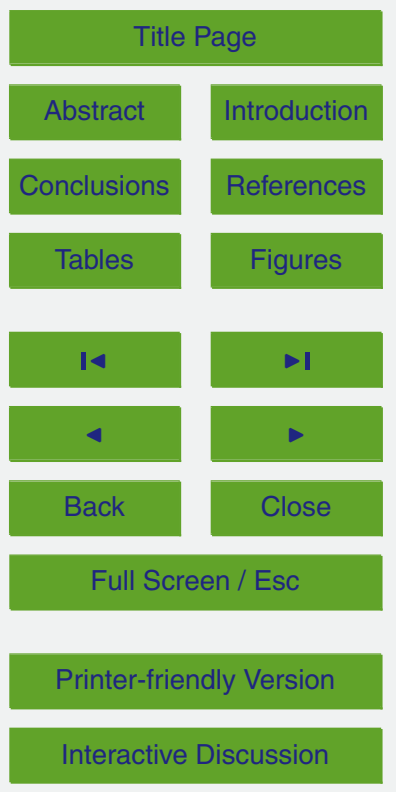


Dubois, P.: Les circulations souterraines dans les calcaires de la région de Montpellier, Bulletin du BRGM, No. 2, Orleans - La Source, 1-31, 1964.

Genthon, P., Bataille, A., Fromant, A., D'Hulst, D., and Bourges, F.: Temperature as a marker for karstic waters hydrodynamics, Inferences from 1 year recording at La Peyrere cave (Ariege,

5 France), J. Hydrol., 311, 157-171, 2005.

Genthon, P., Wirrmann, D., Hoibian, T., and Allenbach, M.: Steady water level and temperature in a karstic system: the case of the coral Lifou Island (SW Pacific), C. R. Geosci., 340, 513522, 2008.

Jemcov, I.: Water supply potential and optimal exploitation capacity of karst aquifer systems, Environ. Geol., 51, 767-773, 2007.

Karanjac, J. and Altug, A.: Karstic spring recession hydrograph and water temperature analysis - Oymapinar Dam Project, Turkey, J. Hydrol., 45, 203-217, 1980.

Kogovsek, J. and Petric, M.: Water temperature as a natural tracer - a case study of the Malenscica karst spring (SW Slovenia), Geol. Croatica, 63, 171-177, doi:10.4154/gc.2010.14, 152010.

Ladouche, B., Dörfliger, N., Pouget, R., Petit, V., Thiery, D., and Golaz, C.: Caractérisation du fonctionnement des systèmes karstiques nord-montpelliérains, Rapport du programme 1999-2001 - Buèges, BRGM/RP-51584-FR, p. 200, 111 fig., 9 tabl., 4 photos, 4 ann., Orleans - La Source, 2002.

20 Ladouche, B., Maréchal, J. C., Dórfliger, N., Lachassagne, P., Lanini, S., and Le Strat, P.: Pompage d'essai sur le système karstique des Cent-Fonts (Cne de Causse de la Selle, Hérault), Présentation et interprétation des données recueillies, BRGM/RP54426-FR, 82 ill., 45 tabl., 9 ann., BRGM, Orleans - La Source, 245 pp., 2005.

LaMoreaux, P. E., Powell, W. J., and LeGrand, H. E.: Environmental and legal aspects of karst areas, Environ. Geol., 29, 23-36, 1997.

Long, A. J. and Gilcrease, P. C.: A one-dimensional heat-transport model for flow conduit in karst aquifers, J. Hydrol., 378, 230-239, 2009.

Lovering, T. S. and Goode, H. D.: Measuring Geothermal Gradients in Drill Holes Less than 20 60 Feet Deep, East Tintic District, Utah, Geological Survey Bulletin, 1172, 1-48, US Govt. Print. Off., Washington, 1963.

Luetscher, M. and Jeannin, P. Y.: Temperature distribution in karst systems: the role of air and water fluxes, Terra Nova, 16, 344-35, 2004.

Assessment of open

thermodynamic

system concepts

P. Machetel and

D. A. Yuen

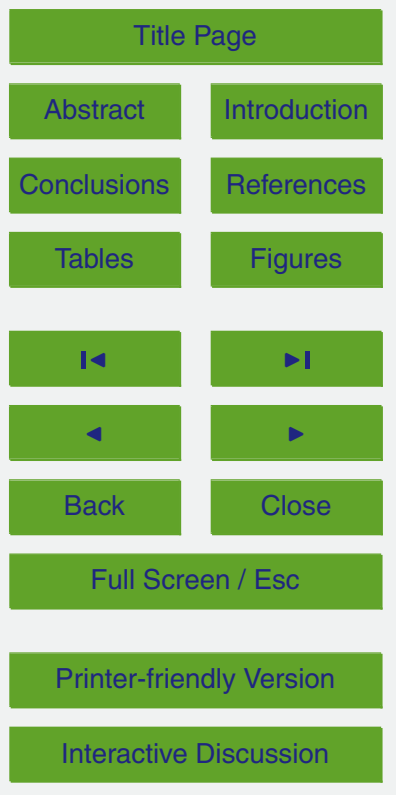


Luhmann, A. J., Covington, M. D., Peters, A. J., Alexander, S. C., Anger, C. T., Green, J. A., Runkel, A. C., and Alexander, E. C.: Classification of thermal patterns at karst spring and cave streams, Ground Water, 49, 324-335, 2011.

Machetel, P. and Yuen, D. A.: Open Thermodynamics System for fluviokarst underground tem5 perature and discharge flow assessment, Abstract H11F-1257 presented at 2012 Fall Meeting, 3-7 December, AGU, San Francisco, Calif., 2012.

Marechal, J. C., Ladouche, B., and Dörfliger, N.: Interpretation of pumping tests in a mixed flow karst system, Water Resour. Res., 44, W05401, doi:10.1029/2007WR006288, 2008.

Paloc, $\mathrm{H}$.: Carte hydrogéologique de la France, région karstique nord-montpelliéraine, notice explicative, Collection des mémoires du BRGM, No. 50, p. 229, 17 pl. fig., 9 pl., Orleans La Source, 1967.

Pechnig, R., Mottaghy, D., Koch, A., Jorand, R., and Clauser, C.: Prediction of thermal properties for Mesozoic rocks of southern Germany, European Geothermal Conference, Geothermische Vereinigung e.V. - Bundesverband Geothermi, Unterhashing, Germany, 2007.

Petelet, E., Luck, J. M., Ben Othman, D., Negrel, P., and Aquilina, L.: Geochemistry and water dynamics of a medium-sized watershed: the Hérault, southern France, 1. Organization of the different water reservoirs as constrained by $\mathrm{Sr}$ isotopes, major, and trace elements, Chem. Geol., 150, 63-83, 1998.

Petelet-Giraud, E., Doerfliger, N., and Crochet, P.: RISKE: Méthode d'évaluation multicritère de la vulnérabilité des aquifères karstiques, Application aux systẽmes des Fontanilles et CentFonts (Hérault, Sud de la France), Hydrogéologie, 4, 71-88, 2000.

Petelet-Giraud, E., Luck, J. M., Ben Othman, D., and Negrel, P.: Dynamic scheme of water circulation in karstic aquifers as constrained by $\mathrm{Sr}$ and $\mathrm{Pb}$ isotopes, Application to the Herault watershed, Southern France, Hydrogeol. J., 11, 560-573, 2003.

Peterson, E. W. and Wicks, C. M.: Fluid and solute transport from a conduit to the matrix in a carbonate aquifer system, Math. Geol., 37, 851-857, doi:10.1007/s11004-005-9211-5, 2005.

Saar, M. O.: Geothermal heat as a tracer of large-scale groundwater flow and as a means to determine permeability fields, Hydrogeol. J., 19, 31-52, 2011.

30 Schoen, R., Bakalowicz, M., Ladouche, B., and Aquilina, L.: Caractérisation du fonctionnement des systèmes karstiques nord-montpelliérains, volume III, Rap. BRGM/R40939, Orleans, 91 pp., 1999.

HESSD

11, 169-198, 2014

\section{Assessment of open \\ thermodynamic \\ system concepts \\ P. Machetel and \\ D. A. Yuen}

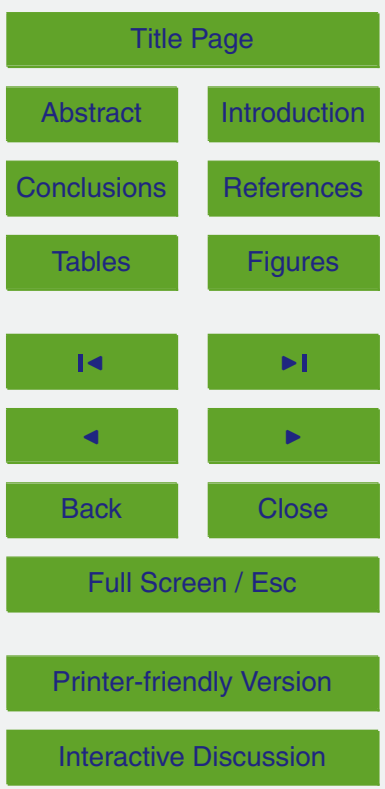


Sinokrot, B. A. and Stefan, H. G.: Stream temperature dynamics measurements and modeling, Water. Resour. Res., 29, 2299-2312, 1993.

Tabbagh, A., Bendjoudi, H., and Benderitter, Y.: Determination of recharge in unsaturated soils using temperature monitoring, Water Resour. Res., 35, 2439-2446, 1999.

5 Van Wylen, G. J. and Sonntag, R. E.: Fundamentals of Classical Thermodynamics, John Wiley \& Sons, New York, 1985.

Vasseur, F.: Inventaire spéléologique des siphons héraultais et des secteurs limitrophes, Fédération française de spéléologie, vol. 1, Lyon, Montpellier, p. 285, 1994.

Vidal, J.: Thermodynamique, Application au génie chimique et à l'industrie pétrolière, Technip ed., Institut Français du Pétrole, Paris, 500 pp., 1997.

Weber, K. A. and Perry, R. G.: Groundwater abstraction impacts on spring flow and base flow in the Hillsborough River Basin, Florida, USA, Hydrogeol. J., 14, 1252-1264, 2006.

White, W. B.: Karst hydrology: recent developments and open questions, Eng. Geol., 65, 85105, 2002.

White, W. B.: Conceptual models for karstic aquifers, in: Karst Modeling: Special Publication 5, edited by: Palmer, A. N., Palmer, M. V., and Sasowsky, I. D., The Karst Waters Institute, Charles Town, West Virginia, USA, 11-16, 1999.

Winter, T. C., Harvey, J. W., Franke, L. O., and Alley, W. M.: Ground water and surface water a single resource, US Geological Survey circular: 1139, 1. Hydrology, edited by: Winter, I. and Thomas, C., II Series, GB661.2.G76, US Geological Survey Denver, Colorado, 1998.

HESSD

$11,169-198,2014$

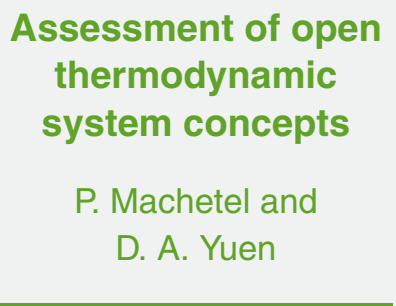

Title Page

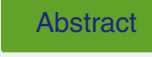

Introduction

Conclusions

Tables

References

Figures

14

$>1$

$\triangleleft$

Back

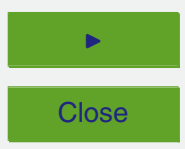

Full Screen / Esc

Printer-friendly Version

Interactive Discussion 
Table 1. Abbreviations.

\begin{tabular}{|c|c|}
\hline \multicolumn{2}{|l|}{ Acronyms } \\
\hline AW & Adiabatic Wall conduit system \\
\hline CS & Conduit System (assumed cylindrical for the study) \\
\hline CW & Conductive Wall conduit system \\
\hline CV & Control volume of the open thermodynamic system \\
\hline PFM & Porous Fractured Matrix \\
\hline \multicolumn{2}{|c|}{ Notations, units, description } \\
\hline$D_{\mathrm{m}}\left(\mathrm{m}^{2} \mathrm{~s}^{-1}\right)$ & Thermal diffusivity of porous matrix \\
\hline$D_{\mathrm{w}}\left(\mathrm{m}^{2} \mathrm{~s}^{-1}\right)$ & Thermal diffusivity of water \\
\hline$\left(m^{2} s^{-1}\right)$ & Kinematic viscosity \\
\hline$N$ & number of $\mathrm{AW}$ in the sequence \\
\hline$Q_{\mathrm{m}}\left(\mathrm{m}^{3} \mathrm{~s}^{-1}\right)$ & total discharge of matrix-conduit flow in the CS \\
\hline$Q_{\mathrm{i}}\left(\mathrm{m}^{3} \mathrm{~s}^{-1}\right)$ & total discharge of intrusion in the CS at swallow zone \\
\hline$Q_{0}\left(\mathrm{~m}^{3} \mathrm{~s}^{-1}\right)$ & total discharge of spring output of the CS \\
\hline$Q_{\mathrm{i}, n}\left(\mathrm{~m}^{3} \mathrm{~s}^{-1}\right)$ & Intrusive flow in the $n$th $\mathrm{CV}$ slice of the AW cases \\
\hline$Q_{\mathrm{m}, n}\left(\mathrm{~m}^{3} \mathrm{~s}^{-1}\right)$ & Discharge of matrix-conduit flow in the $n$th CV slice \\
\hline $\begin{array}{l}Q_{\mathrm{o}, n}\left(\mathrm{~m}^{3} \mathrm{~s}^{-1}\right) \\
r(\mathrm{~m})\end{array}$ & $\begin{array}{l}\text { Output flow in the } n \text {th CV slice } \\
\text { radial coordinate from CS cylindrical axis (positively oriented outward) }\end{array}$ \\
\hline$R_{\mathrm{H}}(\mathrm{m})$ & Hydraulic radius of the $\mathrm{CS}$ \\
\hline$t(\mathrm{~s}$ or -$)$ & time \\
\hline$T(x, r)\left(\mathrm{K}\right.$ or ${ }^{\circ} \mathrm{C}$ or -$)$ & Temperature (function of $x$ and $r$ ) \\
\hline$T_{\infty}\left(\mathrm{K}\right.$ or $\left.{ }^{\circ} \mathrm{C}\right)$ & Far field temperature in the fluviokarst \\
\hline$T_{\mathrm{i}}\left(\mathrm{K}\right.$ or $\left.{ }^{\circ} \mathrm{C}\right)$ & Temperature of the intrusive flow at the swallow zone \\
\hline $\boldsymbol{v}\left(\mathrm{ms}^{-1}\right.$ or -$)$ & Fluid velocity vector \\
\hline$v_{r}(x, r)\left(\mathrm{ms}^{-1}\right.$ or -$)$ & Radial component of velocity (function of $x$ and $r$ ) \\
\hline$v_{x}(x, r)\left(\mathrm{ms}^{-1}\right.$ or -$)$ & $x$ component of velocity (function of $x$ and $r$ ) \\
\hline$x(m$ or -$)$ & $x$ coordinate along the axis of the cylindrical CS \\
\hline \multicolumn{2}{|l|}{ Scales } \\
\hline$L(\mathrm{~m})$ & Scaling for lengths \\
\hline$V\left(\mathrm{~ms}^{-1}\right)$ & Scaling for velocity $\left(V=\left(Q_{S}-Q_{\mathrm{i}}\right) /\left(R_{\mathrm{H}}^{2}\right)\right)$ \\
\hline$\Delta T(\mathrm{~K})$ & Scaling for temperature $\left(\Delta T=T_{\mathrm{i}}-T_{\infty}\right) ;\left(T=\Delta T T^{\prime}+T_{\infty}\right)$ \\
\hline \multicolumn{2}{|c|}{ Dimensionless numbers } \\
\hline$P e(-)$ & Peclet number in the conduit $\left(P e=\angle V / D_{\mathrm{w}}\right)$ \\
\hline $\operatorname{Pr}(-)$ & Prandtl number $\left(\operatorname{Pr}=/ D_{\mathrm{W}}\right)$ \\
\hline$R e_{\mathrm{d}}(-)$ & CS Reynolds number $\left(R e_{\mathrm{d}}=2 V R_{\mathrm{H}} /\right)$ \\
\hline
\end{tabular}

Assessment of open thermodynamic system concepts

P. Machetel and D. A. Yuen

Title Page

Abstract

Conclusions

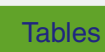

14

4

Back

Introduction

References

Figures

1

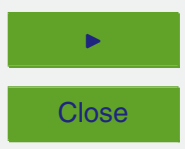

Full Screen / Esc

Printer-friendly Version

Interactive Discussion 


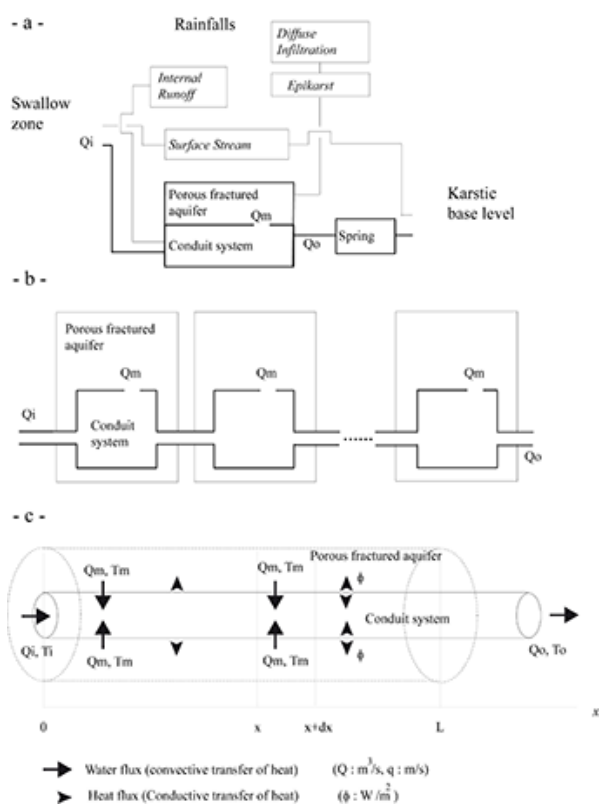

HESSD

11, 169-198, 2014

Assessment of open

thermodynamic

system concepts

P. Machetel and

D. A. Yuen

Title Page

Abstract

Introduction

Conclusions

References

Tables

Figures

Fig. 1. (a) Conceptual fluviokarst structure proposed by White $(2002,2003)$. The karstic aquifer is composed of a swallow zone, of a saturated porous fractured matrix (PFM) drained by a conduit system (CS) and of a spring resurging at the base level. In this work, we have restrained the White's model to recession periods (no surface stream and no run-off flow); (b) a sequence of open thermodynamic system sections with Adiabatic Wall conduit system (AW configuration) is used to describe the fluviokarstic system. Each section represents a slice of CS and PFM constituting a region of space, so-called "control volume" (CV) over which mass and energy balances will be checked; (c) the mixing process of the intrusive flow $\left(Q_{\mathrm{i}}\right)$ and of the matrixconduit flow $\left(Q_{m}\right)$ is analogous to a continuous cooling reaction, which will be modelized taking into account heat conduction within the CS, within the PFM, and from the CS to PFM through the CS Wall (CW configuration).

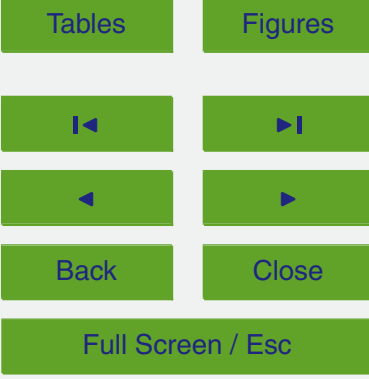

Printer-friendly Version

Interactive Discussion 


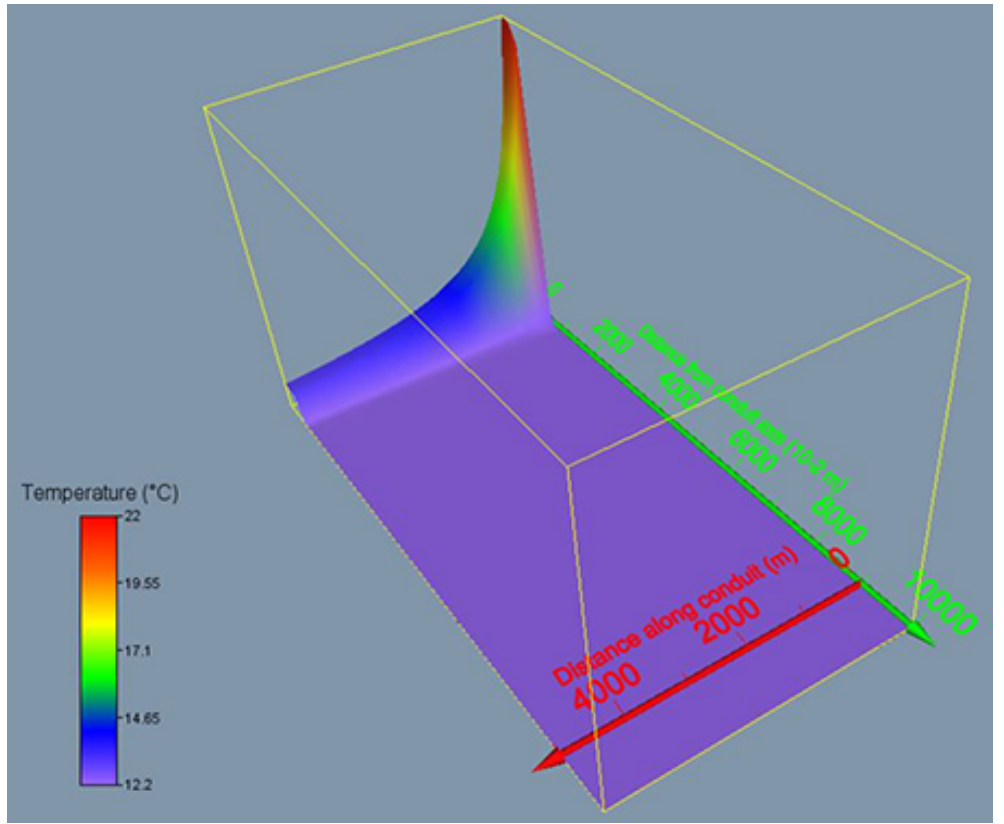

Fig. 2. Illustrative example of the temperature field obtained in the CS and in the PFM with $\mathrm{CW}$ model. Used morphological and physical parameters are characteristic of the Cent-Fonts resurgence $\left(L=5000 \mathrm{~m}, R_{\mathrm{H}}=5 \mathrm{~m}, D_{\mathrm{M}}=4.0310^{-6} \mathrm{~m}^{2} \mathrm{~s}^{-1}, D_{\mathrm{W}}=1.4310^{-7} \mathrm{~m}^{2} \mathrm{~s}^{-1}, T_{\mathrm{i}}=295.25 \mathrm{~K}\right.$ $\left.\left(22.1^{\circ} \mathrm{C}\right), T_{\infty}=285.35 \mathrm{~K}\left(12.2^{\circ} \mathrm{C}\right), Q_{\mathrm{i}}=0.055 \mathrm{~m}^{3} \mathrm{~s}^{-1}, Q_{\mathrm{s}}=0.392 \mathrm{~m}^{3} \mathrm{~s}^{-1}\right)$. These values lead to $P e=1.499310^{8}, R e_{\mathrm{d}}=4.296910^{4}, \operatorname{Pr}=6.9783$ and $D_{\mathrm{M}} / D_{\mathrm{W}}=9.9088$.
HESSD

$11,169-198,2014$

Assessment of open thermodynamic system concepts

P. Machetel and

D. A. Yuen

Title Page

Abstract

Introduction

Conclusions

References

Tables

Figures

14

$\rightarrow 1$

$\triangleleft$

Back

Close

Full Screen / Esc

Printer-friendly Version

Interactive Discussion 


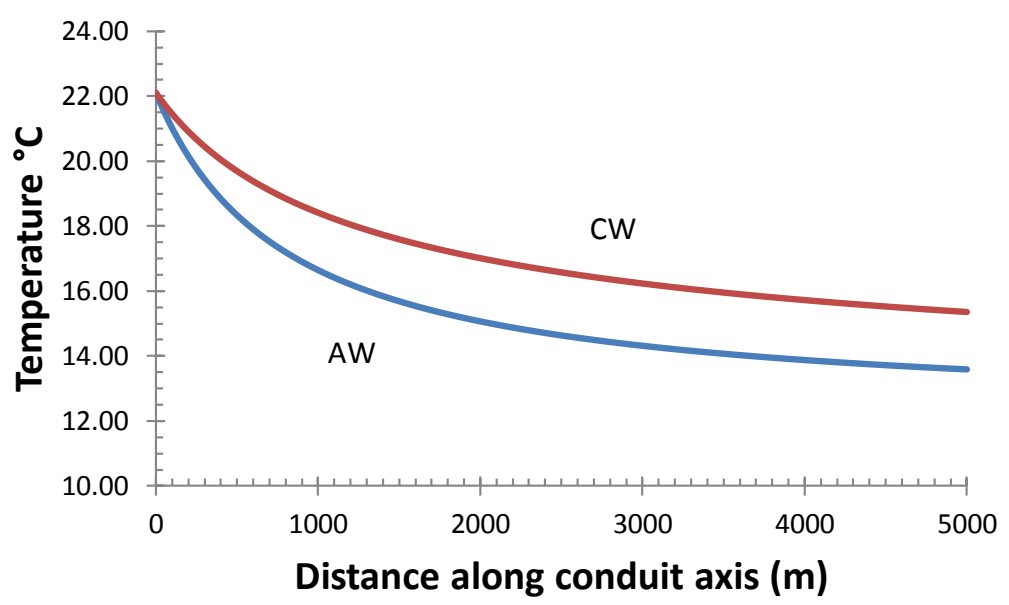

Fig. 3. Comparison of CS temperature obtained with the CW model (red curve) and the AW configurations (blue curve).

\section{HESSD}

11, 169-198, 2014

Assessment of open thermodynamic system concepts

P. Machetel and
D. A. Yuen

Title Page

Abstract Introduction

Conclusions References

14

4

Back

Full Screen / Esc

Printer-friendly Version

Interactive Discussion 

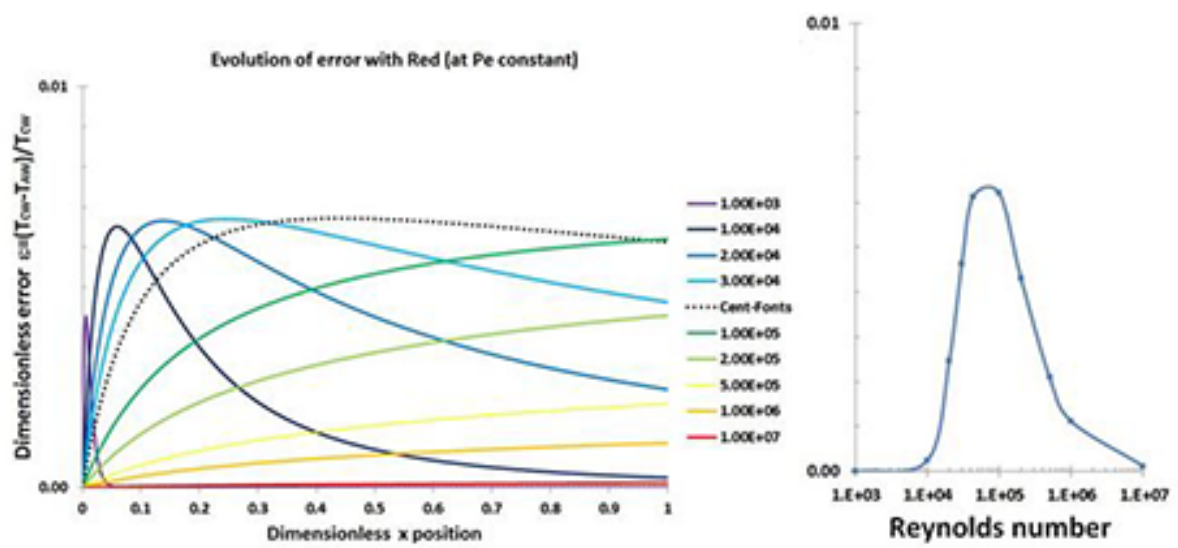

HESSD

11, 169-198, 2014

Assessment of open thermodynamic

system concepts

P. Machetel and

D. A. Yuen

Error at output
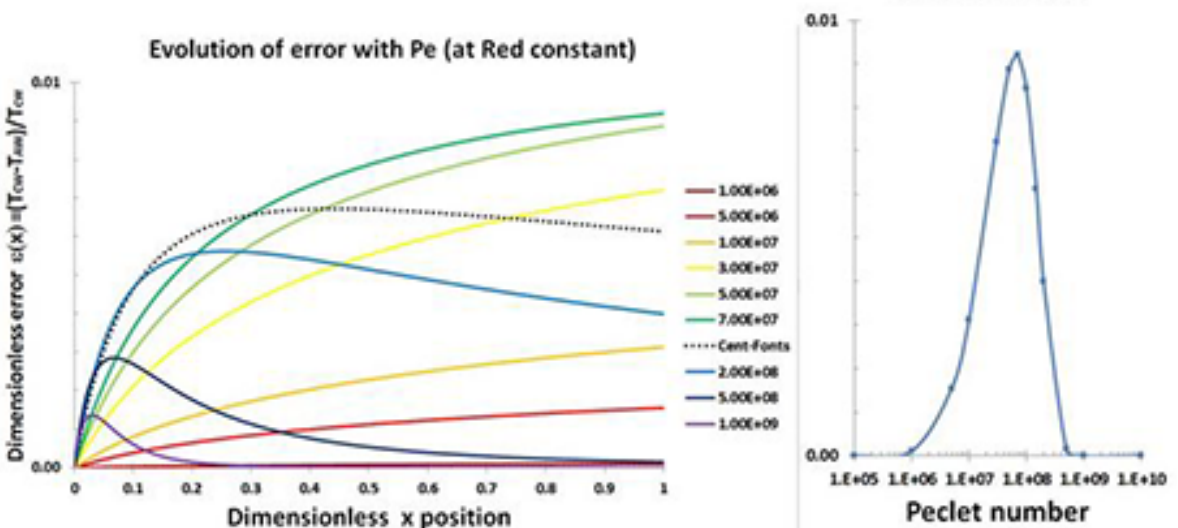

Title Page

Abstract

Introduction

Conclusions

References

Tables

Figures

14

$>1$

$<$

Back

Close

\section{Full Screen / Esc}

Printer-friendly Version

Fig. 4. Evolution of the dimensionless error $\varepsilon(x)$ (Eq. 15) vs. $P e$ (at constant $R e_{\mathrm{d}}$, top panels) and vs. $R e_{\mathrm{d}}$ (at constant $P e$, lower panels). Left panels show the evolution of $\varepsilon(x)$ in the CS while the right panels give a synthetic view of the errors reached at the output of the CS vs. the dimensionless parameters. 


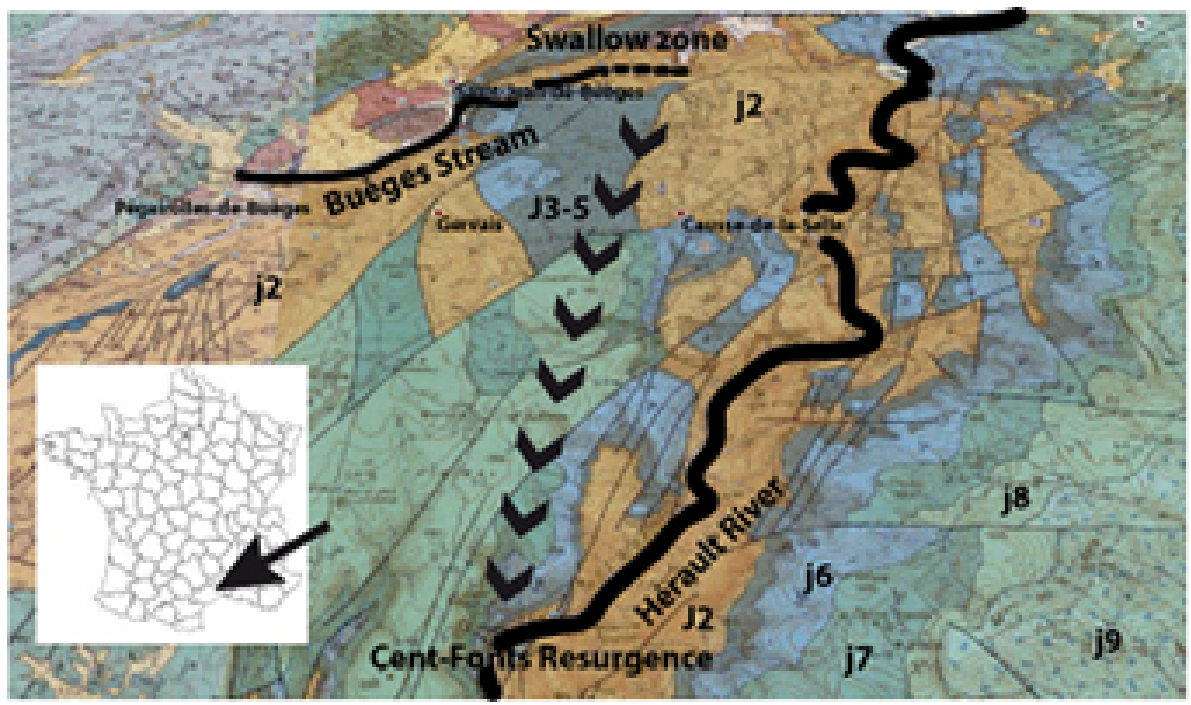

Fig. 5. Cent-Fonts resurgence watershed drawn on the Hérault Geological map 1/50000 France BRGM (J2: Bajocian; J3-5: Bathonian, Callovian, Oxfordian; J6: Kimmeridgian; J7: Tithonian). The Cent-Fonts watershed has been evaluated to 40 to $60 \mathrm{~km}^{2}$ including $10 \mathrm{~km}^{2}$ for the Buèges resurgence watershed (Schoen et al., 1999). It is bound by Cévennes Fault and Buèges Stream at north and northeast. The base level of the fluviokarstic system corresponds to Hérault River that bounds the watershed at south. The Cent-Fonts resurgence drains an epikarstic basic flow and an intrusive underground recharge from the Buèges swallow zone located a few kilometers northernmost.
HESSD

$11,169-198,2014$

\section{Assessment of open \\ thermodynamic \\ system concepts \\ P. Machetel and \\ D. A. Yuen}

Title Page

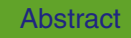

Introduction

Conclusions

References

Tables

Figures

14

Back

$>$

Close

\section{Full Screen / Esc}

Printer-friendly Version

Interactive Discussion 


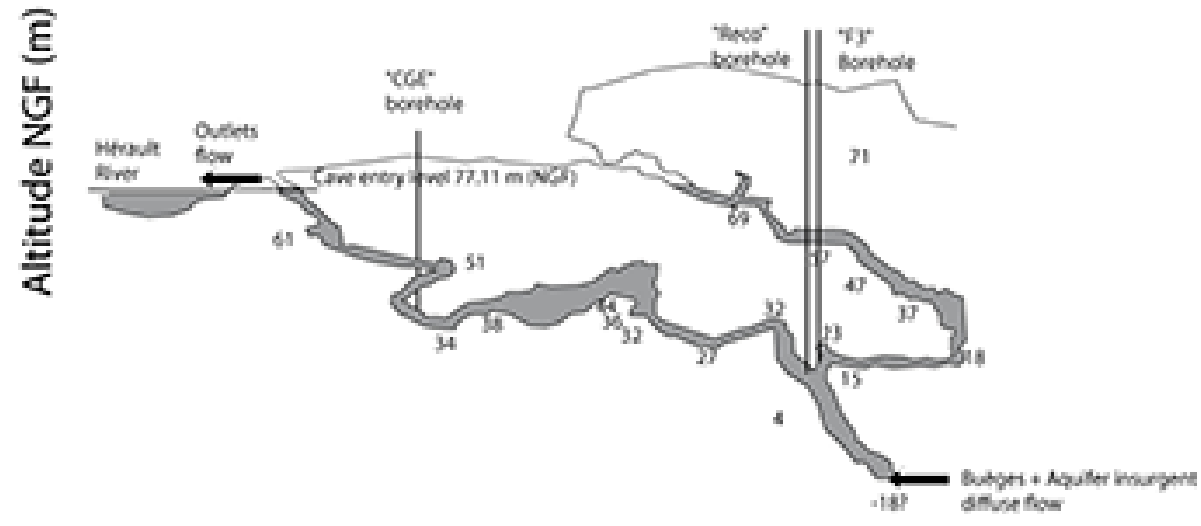

Fig. 6. Unrolled 3-D speleological map of the Cent-Fonts conduit system near the resurgence. Vertical distances $(\mathrm{m})$ are conserved. Depths below the main cave entry are given in $\mathrm{m}$ (italic). During the summer 2005 pumping tests, piezometric heads and temperatures have been measured in the so-called "CGE", "Reco" and "F3" boreholes. Water temperature and discharges were also recorded at the output of the pumping device located in the "F3" borehole, at the entry of the Buèges Stream swallow zone and in the Hérault River near the resurgence (Ladouche et al., 2005).

\section{HESSD}

$11,169-198,2014$

Assessment of open thermodynamic

system concepts

P. Machetel and

D. A. Yuen

Title Page

Abstract Introduction

Conclusions References

Tables Figures

14 $>1$

4

Back

Close

\section{Full Screen / Esc}

Printer-friendly Version

Interactive Discussion 